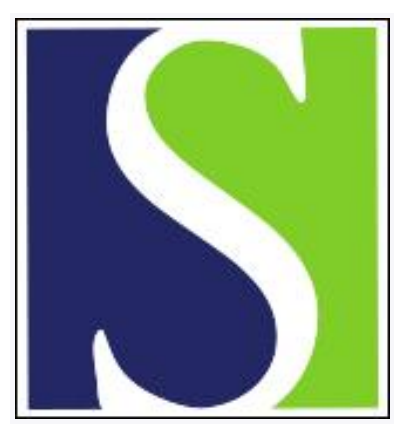

Scand J Work Environ Health 1975;1(4):219-232

https://doi.org/10.5271/sjweh.2844

Issue date: Dec 1975

Blood lead levels and erythrocyte delta-amino-levulinic acid dehydratase activity of selected population groups in Helsinki. by Nordman $\mathrm{CH}$, Hernberg $\mathrm{S}$

Key terms: air; blood; blood lead level; delta-amino-levulinic acid dehydratase activity; delta-aminolevulinic acid dehydratase; erythocyte; Finland; lead; lead level; population group

This article in PubMed: www.ncbi.nlm.nih.gov/pubmed/1228901

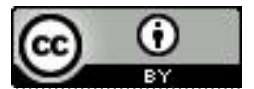




\title{
Blood lead levels and erythrocyte $\delta$-amino- levulinic acid dehydratase activity of selected population groups in Helsinki
}

\author{
by CLAËS HENRIK NORDMAN, M.D., and SVEN HERNBERG, M.D.1
}

\begin{abstract}
NORDMAN, C. H. and HERNBERG, S. Blood lead levels and erythrocyte $\delta$-aminolevulinic acid dehydratase activity of selected population groups in Helsinki. Scand. j. work environ. \& health 1 (1975) $219-232$. The levels of lead in the blood of the adult general population in Helsinki were determind during the period May 1972June 1973. The possibility of occupational exposure to lead was scrupulously excluded. As control groups rural population groups were sampled in the commune of Pertunmaa and the communes of Haapajärvi and Pyhäjärvi. The concentrations of air-suspended particulate lead were studied during 1 year in Helsinki and Pertunmaa; the population groups were sampled from the geographical vicinity of the sampling sites. Care was taken to ensure the accuracy and precision of the analytical methods, the blood lead $(\mathrm{Pb}-\mathrm{B})$ lassay in particular, by continuously checking the methods at experienced laboratories. The annual mean concentration of lead in air in Helsinki ranged from 0.43 to $1.32 \mu \mathrm{g} / \mathrm{m}^{3}$. The corresponding mean at the rural sampling site (Pertunmaa) was $0.025 \mu \mathrm{g} / \mathrm{m}^{3}$. From an international standpoint, the $\mathrm{Pb}-\mathrm{B}$ levels were low. The highest mean $\mathrm{Pb}-\mathrm{B}$ value in groups of the general population occurred in the rural male group $(12.3 \mu \mathrm{g} / 100 \mathrm{mil})$; and the lowest, in the female respondents of the Pertunmaa survey $(7.9 \mu \mathrm{g} / 100 \mathrm{mil})$. A group comprising 86 male streetsweepers from Helsinki displayed a $\mathrm{Pb}-\mathrm{B}$ mean value of $13.3 \mu \mathrm{g} / 100 \mathrm{ml}$, and 28 traffic-directing policemen displayed a mean of $13.5 \mu \mathrm{g} / 100 \mathrm{ml}$, a finding indicating a slight increase in lead absorption. No effect on the $\mathrm{Pb}-\mathrm{B}$ levels of traffic alone was detectable within the general population; thus no statistically significant differences were found between downtown and rural or suburban $\mathrm{Pb}-\mathrm{B}$ levels. The observation that the Pohjois-Haaga suburbanites disclosed higher $\mathrm{Pb}-\mathrm{B}$ levels than did other suburbanites indicates that factors other than traffic should be borne in mind in the assessment of the effect of traffic on lead absorption. The $\delta$-aminolevulinic acid dehydratase (ALAD) assay proved useful and reliable in the discrimination between separate groups whose Pb-B levels differed to a small but measurable extent. The negative correlation between $\mathrm{Pb}-\mathrm{B}$ and ALAD activity was found to prevail at a statistically significant level still at $\mathrm{Pb}-\mathrm{B}$ levels of $10 \mu \mathrm{g}$ / $100 \mathrm{ml}$ or lower.
\end{abstract}

Key words: lead, blood, air, erythrocyte $\delta$-aminolevulinic acid dehydratase, population groups, Helsinki, Finland.

It is known that traffic increases the lead content of air $(9,13,15,33,42,43)$. Furthermore, the isotopic composition of lead aerosols in air indicates that the decomposition products of lead alikyl are the main source of the lead in urban air (10).

1 Department of Epidemiology and Biometry, Institute of Occupational Health, Helsinki, Finland.

Reprinit requests to: Dr. C. H. Nordman, Institute of Occupational Health, Haantmaninkatu 1, FIN-00290 Helsinki 29, Finland.
In close accord with this, several studies have disclosed that exposure to exhaust gases increases blood lead $(\mathrm{Pb}-\mathrm{B})$ levels $(13,23,24,29,33,43,46)$. However, it is still necessary to determine the concentrations of lead in the air which will increase the lead absorption to a measurable extent.

The U.S. Environmental Protection Agency, after a review of studies on the subject, has declared that lead levels of around $2 \mu \mathrm{g} / \mathrm{m}^{2}$ of air induce a measurable increase in $\mathrm{Pb}-\mathrm{B}$ levels among adults (14). 


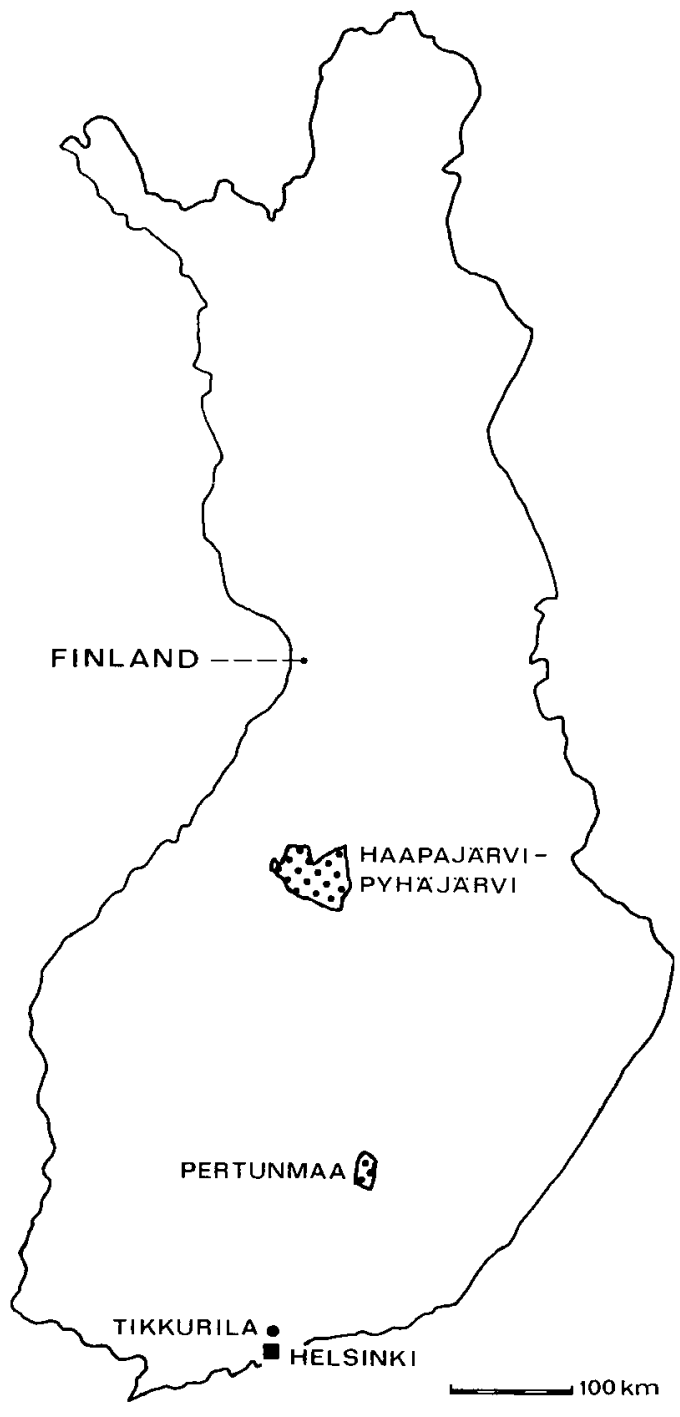

Fig. 1. Location of the rural communes surveyed.

The existence of an association between $\mathrm{Pb}-\mathrm{B}$ levels and lead concentrations has been supported by a controlled 18-week chamber exposure study at about $3 \mu \mathrm{g} / \mathrm{m}^{3}$, which resulted in a rise of $\mathrm{Pb}-\mathrm{B}$ levels (12). In contrast, Tepper and Levin (42) did not find any relationship between annual air lead concentrations, ranging from 0.14 to $4.55 \mu \mathrm{g} / \mathrm{m}^{3}$, and $\mathrm{Pb}-\mathrm{B}$ levels.

Although it is impossible to draw any definite conclusions yet, measures to lower the content of lead in gasoline have been adopted by a number of governments (8). However, little is known about the $\mathrm{Pb}-\mathrm{B}$ levels of Scandinavian populations, and even less about the probable hazards that arise from the probable alternatives replacing lead (5). The commendable decisions made with a view to the reduction of lead pollution are largely based upon results obtained in American population studies. However, the U.S.A. differs from Europe, and from Scandinavia in particular, in many relevant respects, such as the previous use of lead pigments, traffic density, and the degree of industrialization. By reason of the lack of data from Scandinavia, it was decided to study the $\mathrm{Pb}-\mathrm{B}$ levels in Helsinki, and the relationship between them, and to compare urban and rural conditions.

In 1972 Helsinki had about 510,000 residents, i.e., 2,900 inhabitants per square kilometer (Central Statistical Office of Finland). At the time the total number of automobiles registered in Helsinki, according to the owner's domicile, was 110,000 , of which 100,000 were gasoline-powered (From: Automobiles and Highways in Finland 1973, Finnish Road Association). However, the inhabitants of adjacent communes bordering on Helsinki are to a large extent commuters working in the city. When these communes are taken into account, the totals rise to 730,000 people and 140,000 gasoline-powered automobiles, respectively.

Finland has no statute pertaining to the maximum content of lead in gasoline. According to the national refinery, the addition of lead to gasoline has never exceeded $0.7 \mathrm{~g} / \mathrm{l}$ (personal communication, Neste Oy).

\section{MATERIAL AND METHODS}

\section{Selection of population groups}

The population groups under survey were selected from regions surrounding the air sampling sites. Two main population groups were formed in Helsinki: a downtown group derived from employees of the main post office, who both worked and resided within the downtown area, and a suburban group comprising employees, store clerks, and clerical staff working and residing within the suburban districts concerned.

In addition studies were made of two 
target groups with special exposure patterns; these comprised 97 streetsweepers, all of whom had their working place in downtown districts, and 28 of a total of 61 traffic-directing policemen working at the time in Helsinki.

To obtain control groups for the Helsinki series, two rural population groups were selected. One was made up of 33 men and 33 women from the Pentunmaa commune. The other was formed of 93 female post office employees from Haapajärvi and Pyhäjärvi communes (fig. 1). The rural communes of Haapajärvi and Pyhäjärvi are both situated about 400 kilometers north of Helsinki, with about 8,000 inhabitants and less than 1,500 automobiles each. The number of inhabitants per square kilometer is 5.9 for Pyhäjärvi and 9.9 for Haapajänvi (Central Statistical Office of Finland). The corresponding data for Pertunmaa are 7.4 inhabitants per square kilometer and 562 automobiles (Central Statistical Office of Finland).

Distributions by age and sex of the different groups are indicated in table 1; and smoking habits, in table 2.

\section{Aerometric sampling}

The sampling of air-suspended particulate lead was effected at four fixed sampling sites. The downtown sampling site (no 1) was situated about $300 \mathrm{~m}$ from the main post office, close to the city railroad station (fig. 2). Sampling site 2 was situated in a mixed commercial, industrial, and residential area; sampling site 3 , in the suburb of Pohjois-Haaga; and sampling site 4 , in the suburb of Otaniemi.

The sampling equipment for air-suspended particulate matter comprised a holder with a membrane filter (Millipore AAWP 03700) with a pore diameter of $0.8 \mu \mathrm{m}$, and a pump supplying an air flow of about 10 1/min (Neuberger $\mathrm{V} \mathrm{H} \mathrm{15).} \mathrm{For}$ measurement of the terminal air flow, each sampling device was fitted with a gasomater (Nordgas, Stockholm). Air lead was collected on the filters as dust in sampling cycles of 2 weeks. The sampling devices were placed at a height of $2.5-3.5 \mathrm{~m}$.

The sampling continued at all sampling sites for 1 year. Although air sampling at some sampling sites was effected for more than 1 year, the results reported here relate only to the period from November 1971 through October 1972; the reliability of the analytical techniques was not regarded as satisfactory before that. Atmospheric lead sampling was carried out in Pertunmaa and Helsinki.

\section{Collection of biological data}

Two factors influenced the choice of the time for collecting the biological samples. First it was assumed that the streetsweepers' springcleaning of the streets was finished by the end of April, a time which implied a maximum exposure to street dust. Secondly the possibility of seasonal variation had to be excluded. The streetsweepers were thus examined concomitantly with the downtown group, half of the suburban group, and the Pertunmaa

Table 1. Distribution of different urban and rural population groups by age and sex.

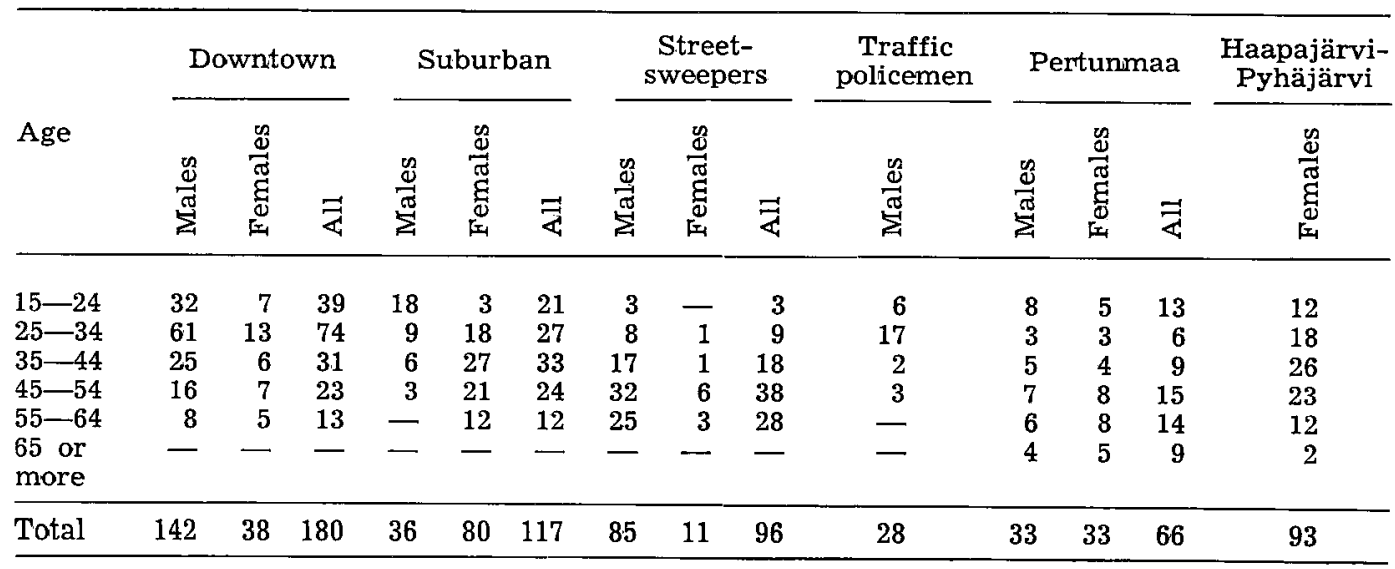


Table 2. Smoking habits of different urban and rural population groups.

\begin{tabular}{|c|c|c|c|c|c|}
\hline \multirow{2}{*}{ Group } & \multicolumn{3}{|c|}{ Cigarettes daily } & \multirow{2}{*}{$\begin{array}{l}\text { Pipe or } \\
\text { cigars }\end{array}$} & \multirow{2}{*}{ Nonsmokers } \\
\hline & $>20$ & $10-20$ & $<10$ & & \\
\hline \multicolumn{6}{|l|}{ Downtown } \\
\hline Males & 17 & 42 & 13 & 6 & 69 \\
\hline Females & 1 & 9 & 7 & - & 22 \\
\hline All & 18 & 51 & 20 & 6 & 91 \\
\hline \multicolumn{6}{|l|}{ Suburban } \\
\hline Males & 4 & 9 & 6 & 2 & 16 \\
\hline Females & 1 & 13 & 12 & 1 & 56 \\
\hline All & 5 & 22 & 18 & 3 & 72 \\
\hline \multicolumn{6}{|c|}{ Streetsweepers } \\
\hline Males & 12 & 20 & 8 & 2 & 44 \\
\hline Females & 一 & 1 & - & - & 10 \\
\hline All & 12 & 21 & 8 & 2 & 54 \\
\hline \multicolumn{6}{|l|}{ Policemen } \\
\hline Males & 2 & 5 & 3 & - & 18 \\
\hline \multicolumn{6}{|l|}{$\begin{array}{l}\text { Haapajärvi- } \\
\text { Pvhäjärvi }\end{array}$} \\
\hline \multicolumn{6}{|c|}{$\begin{array}{c}\text { Pyhäjärvi } \\
\text { Females }\end{array}$} \\
\hline & 一 & 3 & 18 & - & 72 \\
\hline \multicolumn{6}{|l|}{ Pertunmaa } \\
\hline Males & 1 & 5 & 4 & - & 23 \\
\hline Females & - & - & 3 & - & 30 \\
\hline All & 1 & 5 & 7 & - & 53 \\
\hline
\end{tabular}

group firom the end of May through the end of June 1972, and the HaapajärviPyhäjärvi group in August 1972. For practical reasons examination of the other half of the suburban group had to be postponed until June 1973. The policemen were examined as early as in November 1971, however.

All of the blood and dietary samples collected for the determination of lead content were stored in lead-free polyethene flasks or bottles which had been carefully washed with $10 \%$ nitric acid and repeatedly rinsed with demineralized, distilled water.

Blood samples were drawn from a cubital vein into lead-free flasks. Only stainless steel syringes with polypropylene hubs were used. The skin was cleaned with a $0.2 \%$ benzethone chloride solution containing $2.9 \%$ butanol and, as the solvent, $68.9 \%$ isopropanol. An amount of $20 \mathrm{ml}$ of blood was drawn from each person for $\mathrm{Pb}-\mathrm{B}$ analysis; duplicate samples were drawn from every fifth person for storage and future analysis. The $\mathrm{Pb}-\mathrm{B}$ flasks were stored deep-frozen until analysis. Samples for the determination of erythrocyte $\delta$ aminolevulinic acid dehydratase (ALAD) were drawn into heparinized test tubes of 10-ml capacity. Otherwise the test tubes were prepared analogously with the $\mathrm{Pb}-\mathrm{B}$ flasks. For determination of the hematocrit value and the hemoglobin concentration, $2.5 \mathrm{ml}$ of blood was drawn inito a test tube containing $4 \mathrm{mg}$ of ethylenediamine tetraacetate (EDTA).

\section{Analytical methods}

All of the Pb-B samples, except for those of the 29 policemen, were intermixed and analyzed in series made up by proportional amounts from each group, for the avoidance of systematic errors.

$\mathrm{Pb}-\mathrm{B}$ determinations were performed from duplicate samples; thus the reported results of each analysis denotes the average of two parallel measurements. The duplicate samples were analyzed in different runs. The method employed throughout was that of atomic absorption spectrophotometry (Perkin-Elmer 303), described by Hessel (22). A series of 26 duplicate samples analyzed unbeknown to the laboratory personnel showed a method error of $1.7 \mu \mathrm{g} / 100 \mathrm{ml}$; the method error reported by the laboratory for the same period was $1.1 \mu \mathrm{g} / 100 \mathrm{ml}$. The method was 
continuously checked by the introduction of spiked samples.

During the period from July, 1972, to June, 1973, the monthly determinations of three spiked pig blood samples, to which $30 \mu \mathrm{g}$ of lead $\left(\mathrm{PbCl}_{2}\right)$ per $100 \mathrm{ml}$ of blood had been added (a total of 36 samples), resulted in a mean value of $34.0 \mu \mathrm{g} / 100 \mathrm{ml}$, a standard deviation of 1.7 , and a range of $20.5-37.7 \mu \mathrm{g} / 100 \mathrm{ml}$. During the same period, a series of 12 human blood samples, to which had been added the same amount $(30 \mu \mathrm{g} \mathrm{Pb} / 100 \mathrm{ml})$ of lead, were analyzed monthly without the knowledge of the laboratory staff. These gave a mean of 46.7 , a standard deviation of 3.6 , and a range of $42.3-52.5 \mu \mathrm{g} / 100 \mathrm{ml}$. Unspiked duplicates were currently analyzed. The mean estimated value of the added amount of lead was $31.4 \mu \mathrm{g} / 100 \mathrm{ml}$. New spiked samples were prepared once a month.

The accuracy of the $\mathrm{Pb}-\mathrm{B}$ method was further controlled within the compass of an inter-Scandinavian comparison program. Spiked and unspiked blood samples were distributed to the eight Scandinavian laboratories involved. The results of the interlaboratory comparison are presented in tables 3 and 4.

A series of duplicate samples were also analyzed twice a year in the laboratory of the American Smelting and Refining Company (ASARCO), Utah, U.S.A. These are accounted for in table 5 . The samples

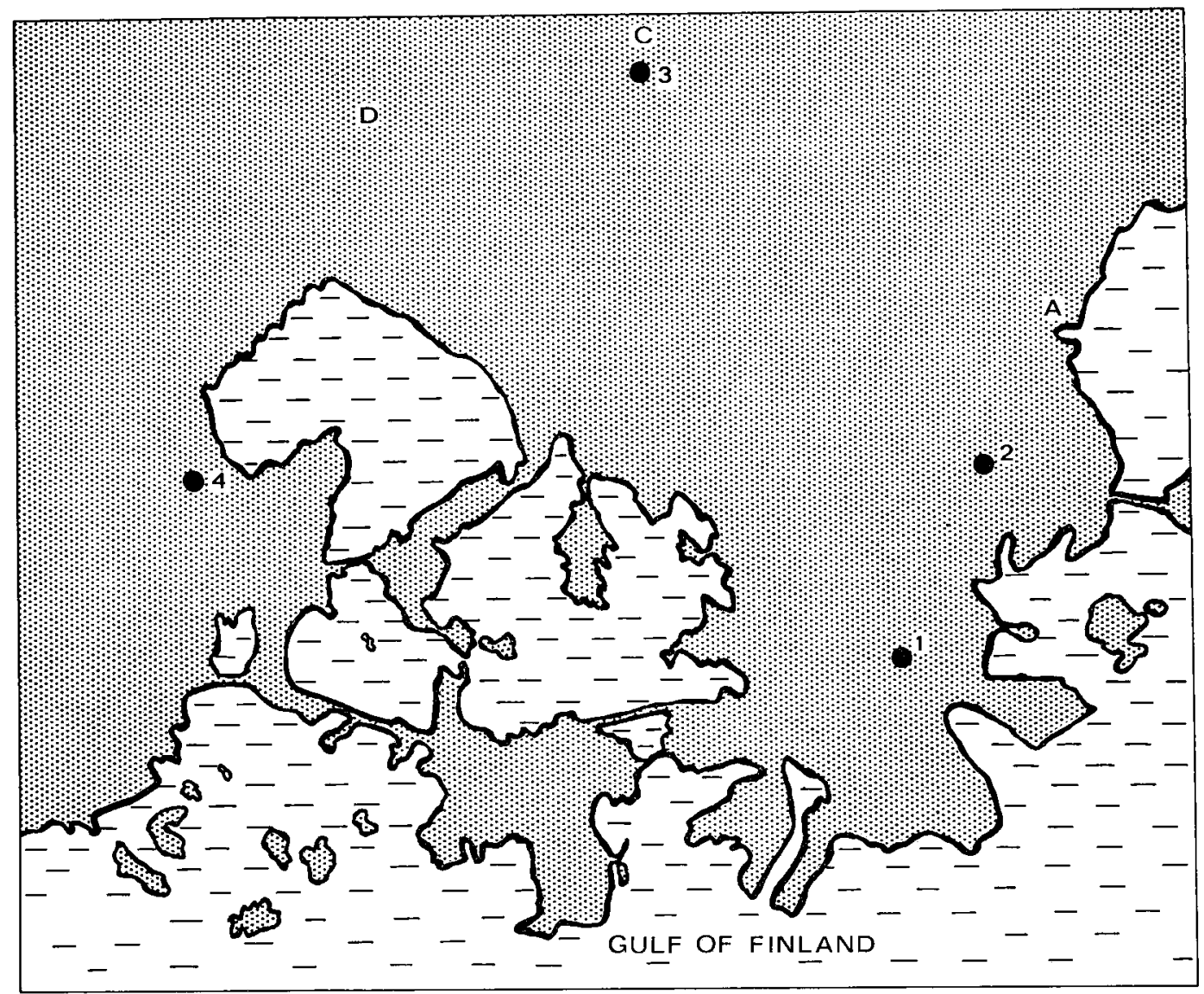

Fig. 2. Air sampling sites in Helsinki. Sampling site no. $1=$ downtown, no. $2=$ mixed traffic-industrial-residential, no. $3=$ suburb of Pohjois-Haaga, no. $4=$ suburb of Otaniemi. A = Helsinki main incinerator, $B=$ Tikkurila lead emitters at a distance of about $10 \mathrm{~km}$ from sampling site no. $3, \mathrm{C}=$ Haaga no. 3 power station, $\mathrm{D}=$ lead pigment plant. 
of both the accuracy control programs were first analyzed at the Institute of Occupational Health, and the results were passed to the reference laboratories con-

Table 3. Comparative inter-Scandinavian check of blood lead determination. Values expressed as $\mu \mathrm{g} / 100 \mathrm{ml}$.

\begin{tabular}{lcrc}
\hline $\begin{array}{l}\text { Time of } \\
\text { check }\end{array}$ & $\begin{array}{r}\text { Mean of 8 } 8 \\
\text { laboratories }\end{array}$ & $\begin{array}{c}\text { Range of } 8 \\
\text { laboratories }\end{array}$ & $\begin{array}{c}\text { Present } \\
\text { value }\end{array}$ \\
\hline Spring & 14 & $10-18$ & 17 \\
1972 & 14 & $9-17$ & 17 \\
& 51 & $44-61$ & 61 \\
& 85 & $80-95$ & 95 \\
& 85 & $81-93$ & 93 \\
Spring & 87 & $80-94$ & 94 \\
1973 & 7 & $5-13$ & 12 \\
& 8 & $5-17$ & 12 \\
& 26 & $24-41$ & 31 \\
& 40 & $38-51$ & 44 \\
& 76 & $74-104$ & 82 \\
\hline
\end{tabular}

cerned before reports of their results had been received.

Erythrocyte ALAD activity was measured by a modified version of the method of Bonsignore and his colleagues $(6,37)$. Briefly, the modification involves the use of the more stable sodium phosphate buffer and a $\mathrm{pH}$ of 6.8 , instead of a carbonate buffer and a $\mathrm{pH}$ of 7.0. The activity is expressed as micromols porphobilinogen (PBG) formed during $1 \mathrm{~h}$ of incubation at $37^{\circ} \mathrm{C}$ per liter of packed red blood cells (RBC). The RBC volume was estimated from the hematocrit value measured previously. The ALAD assay showed a method error from duplicate measurements of $18.4 \mu \mathrm{mol}$ PBG per liter RBC. All of the ALAD alssays were made within 5 $h$ of sampling.

The hematocrit value was measured

Table 4. Inter-Scandinavian accuracy check of blood lead determination. Values expressed as $\mu \mathrm{g} / 100 \mathrm{ml}$.

\begin{tabular}{lcccc}
\hline & & \multicolumn{3}{c}{ Calculated values } \\
\cline { 3 - 5 } Time of check & Lead added & $\begin{array}{c}\text { Mean of } 8 \\
\text { laboratories }\end{array}$ & $\begin{array}{c}\text { Range of } 8 \\
\text { laboratories }\end{array}$ & Present value \\
\hline \multirow{2}{*}{ Spring } & 38.4 & 38 & $31-44$ & 44 \\
1972 & 77 & 72 & $67-78$ & 78 \\
& 77 & 72 & $65-76$ & 77 \\
Spring & 77 & 74 & $67-79$ & 19 \\
1973 & 19 & 21 & $18-30$ & 32 \\
& 32 & 34 & $29-40$ & 70 \\
\hline
\end{tabular}

Table 5. American accuracy check of blood lead determination in 1972. Values expressed as $\mu \mathrm{g} / 100 \mathrm{ml}$.

\begin{tabular}{|c|c|c|c|c|c|}
\hline $\begin{array}{c}\text { Sample } \\
\text { no. }\end{array}$ & $\begin{array}{l}\text { ASARCOa } \\
\text { value }\end{array}$ & $\begin{array}{l}\text { Present } \\
\text { value }\end{array}$ & $\begin{array}{c}\text { Sample } \\
\text { no. }\end{array}$ & $\begin{array}{l}\text { ASARCOa } \\
\text { value }\end{array}$ & $\begin{array}{c}\text { Present } \\
\text { value }\end{array}$ \\
\hline 1 & 21 & 12 & 14 & 43 & 53 \\
\hline 2 & 12 & 10 & 15 & 57 & 47 \\
\hline 3 & 19 & 19 & 16 & 43 & 56 \\
\hline 4 & 70 & 86 & 17 & 8 & 9 \\
\hline 5 & 54 & 73 & 18 & 7 & 7 \\
\hline 6 & 66 & 74 & 19 & 8 & 8 \\
\hline 7 & 57 & 64 & 20 & 10 & 8 \\
\hline 8 & 64 & 77 & 21 & 15 & 15 \\
\hline 9 & 76 & 79 & 22 & 12 & 13 \\
\hline 10 & 64 & 71 & 23 & 6 & 9 \\
\hline 11 & 54 & 63 & 24 & 11 & 12 \\
\hline 12 & 49 & 60 & 25 & 7 & 8 \\
\hline 13 & 57 & 72 & 26 & 10 & 10 \\
\hline
\end{tabular}

aAmerican Smelting and Refining Company, Utah, U.S.A. 
with an Adams Autocrit Centrifuge (CT 2900). Duplicate blood samples were spun for $4 \mathrm{~min}$ at $15,000 \mathrm{~g}$.

Blood hemoglobin was determined by the standard method, after conversion to cyanmethemoglobin.

The air-suspended particulate matter obtained on the membrane filters was analyzed for lead directly by X-ray fluorescence spectrometry (Philips PW 1410). A lithium-fluoride crystal $(\mathrm{LiF} 200)$, and a wolfram anode itube were employed. The $\mathrm{X}$-ray generator was set at $60 \mathrm{kV}$ and $30 \mathrm{~mA}$. Lead was determined from the alpha-line, 2-theta angle $=33.91$. Measurement was effected three times, each one extending over a 20 -s period. The background was determined at a 2-theta angle of $34.50(16,38)$. The method was checked by parallel determination with atomic absorption spectrophotometry. The comparison is accounted for in table 6 .

\section{RESULTS}

\section{Lead in air}

Monthly and annual mean values for lead in urban and rural air are listed in table 7. The highest annual mean value of $1.32 \mu \mathrm{g} /$ $\mathrm{m}^{3}$ was measured at the Helsinki down- town sampling site; it was about 50 times the rural yearly mean value of $0.025 \mu \mathrm{g} /$ $\mathrm{m}^{3}$. The monthly means at this urban sampling site ranged from 0.68 to $2.20 \mu \mathrm{g} /$ $\mathrm{m}^{3}$, while the rural monthly mean never exceeded $0.06 \mu \mathrm{g} / \mathrm{m}^{3}$. The suburban sampling site no. 3 displayed a higher yearly mean than did sampling site 2 . The

Table 6. Comparison between X-ray fluorescence spectrametry and atomic absorption spectrophotometry. Values expressed as micrograms per sample.

\begin{tabular}{|c|c|c|c|c|c|}
\hline \multicolumn{3}{|c|}{ May_July 1973} & \multicolumn{3}{|c|}{ August 1973} \\
\hline $\begin{array}{l}\text { Sample } \\
\text { no. }\end{array}$ & $\begin{array}{l}X- \\
\text { ray }\end{array}$ & AAS & $\begin{array}{c}\text { Sample } \\
\text { no. }\end{array}$ & $\begin{array}{l}\mathrm{X}- \\
\text { ray }\end{array}$ & AA \\
\hline 1 & 261 & 143 & 18 & 520 & 666 \\
\hline 2 & 26 & 23 & 19 & 165 & 205 \\
\hline 3 & 2 & 3 & 20 & 62 & 61 \\
\hline 4 & 460 & 449 & 21 & 32 & 37 \\
\hline 5 & $1, \mathbf{1 7 0}$ & 819 & 22 & 7 & 6 \\
\hline 6 & 1,246 & 774 & 23 & 22 & 19 \\
\hline 7 & 1,035 & 552 & 24 & 37 & 33 \\
\hline 8 & 105 & 93 & 25 & 24 & 20 \\
\hline 9 & 1,255 & 1,172 & 26 & 202 & 198 \\
\hline 10 & 581 & 633 & & & \\
\hline 11 & 50 & 55 & & & \\
\hline 12 & 103 & 132 & & & \\
\hline 13 & 86 & 87 & & & \\
\hline 14 & 47 & 52 & & & \\
\hline 15 & 10 & 22 & & & \\
\hline 16 & 25 & 34 & & & \\
\hline 17 & 55 & 73 & & & \\
\hline
\end{tabular}

Table 7. Monthly and yearly mean values of air-suspended particulate lead in Helsinki. Values expressed as $\mu \mathrm{g} / \mathrm{m}^{3}$. Numbers of sampling sites refer to area as follows: $1=$ downtown, $2=$ mixed industrial-traffic-residential, 3 and $4=$ suburban.

\begin{tabular}{|c|c|c|c|c|c|}
\hline \multirow{2}{*}{$\begin{array}{l}\text { Period of } \\
\text { sampling }\end{array}$} & \multicolumn{4}{|c|}{ Helsinki sampling site no. } & \multirow{2}{*}{ Pertunmaa } \\
\hline & 1 & 2 & 3 & 4 & \\
\hline \multicolumn{6}{|l|}{1971} \\
\hline November & -a & 一 & 1.10 & 0.46 & 0.02 \\
\hline December & 2.20 & 1.30 & 1.40 & 0.76 & 0.02 \\
\hline \multicolumn{6}{|l|}{1972} \\
\hline January & 1.70 & 1.30 & 1.20 & 0.62 & 0.06 \\
\hline February & 1.80 & 0.97 & 1.50 & 0.33 & 0.06 \\
\hline March & 1.20 & - & 1.20 & - & 0.03 \\
\hline April & 1.80 & 0.38 & 0.67 & - & 0.01 \\
\hline May & 0.74 & 0.83 & 0.80 & 一 & - \\
\hline June & 0.87 & 0.92 & 0.91 & - & 0.02 \\
\hline July & 0.68 & 0.59 & 0.67 & 0.16 & 0.01 \\
\hline August & 1.10 & 0.90 & 1.02 & 0.18 & 0.02 \\
\hline September & 1.40 & 0.85 & 1.18 & 0.47 & 0.02 \\
\hline October & 1.55 & 1.00 & 1.13 & 0.52 & - \\
\hline Annual mean & 1.32 & 0.90 & 1.05 & 0.43 & 0.025 \\
\hline
\end{tabular}

a Stroke denotes emission of sample. 
Table 8. Blood lead levels of different urban and rural population groups. Values expressed as $\mu \mathrm{g} / 100 \mathrm{ml}$ of blood. ( $\mathrm{N}=$ number, $\mathrm{M}=$ mean, $\mathrm{SD}=$ standard deviation).

\begin{tabular}{|c|c|c|c|c|c|c|c|c|c|c|c|c|}
\hline & \multicolumn{6}{|c|}{ Males } & \multicolumn{6}{|c|}{ Females } \\
\hline & $\begin{array}{l}\text { Pol- } \\
\text { ice- } \\
\text { men }\end{array}$ & $\begin{array}{l}\text { Street- } \\
\text { sweep- } \\
\text { ers }\end{array}$ & $\begin{array}{l}\text { Hels } \\
\text { Down- } \\
\text { town }\end{array}$ & $\begin{array}{l}\text { sinki } \\
\text { Sub- } \\
\text { urban }\end{array}$ & $\begin{array}{l}\text { Per- } \\
\text { tun- } \\
\text { maa }\end{array}$ & $\begin{array}{l}\text { Pyhä- } \\
\text { järvi }\end{array}$ & $\begin{array}{l}\text { Pol- } \\
\text { ice- } \\
\text { men }\end{array}$ & $\begin{array}{l}\text { Street- } \\
\text { sweep- } \\
\text { ers }\end{array}$ & $\begin{array}{l}\text { Hels } \\
\text { Down- } \\
\text { town }\end{array}$ & $\begin{array}{l}\text { Sinki } \\
\text { Sub- } \\
\text { urban }\end{array}$ & $\begin{array}{l}\text { Per- } \\
\text { tun- } \\
\text { maa }\end{array}$ & $\begin{array}{l}\text { Pyhä- } \\
\text { järvi }\end{array}$ \\
\hline $\mathrm{N}$ & 28 & 86 & 142 & 37 & 33 & $\ldots$ & - & 11 & 37 & 81 & 33 & 93 \\
\hline M & 13.5 & 13.3 & 11.4 & 10.6 & 12.3 & - & - & 10.4 & 8.5 & 9.7 & 7.9 & 8.6 \\
\hline SD & 2.8 & 4.1 & 3.3 & 2.8 & 3.3 & - & - & 3.0 & 2.0 & 2.6 & 1.9 & 2.5 \\
\hline $\min$ & 9 & 7 & 5 & 6 & 5 & - & - & 5 & 6 & 6 & 5 & 4 \\
\hline $\max$ & 20 & 29 & 23 & 18 & 19 & - & - & 15 & 14 & 20 & 12 & 20 \\
\hline
\end{tabular}

Otaniemi sampling site had a yearly average of $0.43 \mu \mathrm{g} / \mathrm{m}^{3}$. Seasonal fluctuations were observable in the monthly means, with a tendency towards lower values during the summer months and achievement of the highest values in the autumn and winter months.

\section{Lead in blood}

Table 8 lists the mean $\mathrm{Pb}-\mathrm{B}$ values of the different population groups together with the standard deviations of the means and the ranges. The most conspicuous feature of the results is that no subgroup displayed a mean $\mathrm{Pb}-\mathrm{B}$ value exceeding $13.5 \mu \mathrm{g} /$ $100 \mathrm{ml}$. The highest mean values were found in the groups of policemen and male streetsweepers, i.e., 13.5 and $13.3 \mu \mathrm{g} / 100 \mathrm{ml}$ of iblood, respectively. Both are higher than the means of the other urban male groups. When the male streetsweepers were tested for significance against the male downtown group, they yielded a tvalue of 3.64 , corresponding to a $p$-value of $<0.001$. The level of significance was similar when tested against the suburban males ( $\mathrm{t}=4.23, \mathrm{p}<0.001)$. No statistically significant differences were found between downtown and suburban or rural males. The rural males had higher $\mathrm{Pb}-\mathrm{B}$ values than the suburban males $(t=2.31, p<$ 0.05). Throughout, the $\mathrm{Pb}-\mathrm{B}$ values of the females were lower than those of the males. The highest mean was exhibited by the 11 female streetsweepers; however, this group was small and has consequently been omitted from the statistical calculations. Surprisingly the suburban females exhibited a mean value that
Table 9. Lead in blood of suburbanites of Pohjois-Haagia as compared to other suburbanites.

\begin{tabular}{|c|c|c|c|c|}
\hline \multicolumn{3}{|c|}{ Males } & \multicolumn{2}{|c|}{ Females } \\
\hline & $\begin{array}{c}\text { Poh- } \\
\text { jois- } \\
\text { Haaga }\end{array}$ & $\begin{array}{l}\text { Other } \\
\text { suburb- } \\
\text { anites }\end{array}$ & $\begin{array}{c}\text { Poh- } \\
\text { jois- } \\
\text { Haaga }\end{array}$ & $\begin{array}{c}\text { Other } \\
\text { suburb- } \\
\text { anites }\end{array}$ \\
\hline $\mathrm{N}$ & 8 & 28 & 27 & 53 \\
\hline $\mathrm{M}$ & 13.1 & 10.0 & 10.9 & 9.2 \\
\hline SD & 3.2 & 2.3 & 3.4 & 1.9 \\
\hline $\mathrm{t}$ & \multirow{2}{*}{\multicolumn{2}{|c|}{$\begin{array}{l}2.56 \\
<0.05\end{array}$}} & \multirow{2}{*}{\multicolumn{2}{|c|}{2.41}} \\
\hline $\mathrm{p}$ & & & & \\
\hline
\end{tabular}

exceeded those of the other female groups. This diversity was statistically significant when tested against the downtown group $(t=2.74, p<0.01)$, the Pentunmaa group $(t=4.10, p<0.001)$, and the HaapajärviPyhäjärvi group $(t=2.84, p<0.01)$. Only insignificant differences were apparent between downtown and rural females. For elucidation of whether any dependence existed between the finding of unexpectedly high lead concentrations in air at suburban sampling site no. 3 and the higher $\mathrm{Pb}-\mathrm{B}$ values of the suburban females, a subdivision was made of the suburban group. Comparisons were drawn between the population living within 1 kilometer of sampling site no 3 (PohjoisHaaga) and all of the other suburbanites (table 9). This comparison revealed that the mean $\mathrm{Pb}-\mathrm{B}$ value was higher for the Pohjois-Haaga group than for the others and applied both to males and to females. The arbitrarily composed group of "other suburban" females did not differ from downtown or Haapajärvi-Pyhäjärvi fe- 
Table 10. Erythrocyte $\delta$-aminolevulinic acid dehydratase activity for different urban and rural population groups. Values expressed as $\mu \mathrm{mol} / \mathrm{PBG} / \mathrm{h} / \mathrm{l} \mathrm{RBC}$.

\begin{tabular}{|c|c|c|c|c|c|c|c|c|}
\hline & \multicolumn{4}{|c|}{ Males } & \multicolumn{4}{|c|}{ Females } \\
\hline & $\begin{array}{c}\text { Street- } \\
\text { sweepers }\end{array}$ & $\begin{array}{l}\text { Down- } \\
\text { town }\end{array}$ & $\begin{array}{c}\text { Sub- } \\
\text { urban }\end{array}$ & All & $\begin{array}{c}\text { Street- } \\
\text { sweepers }\end{array}$ & $\begin{array}{c}\text { Down- } \\
\text { town }\end{array}$ & $\begin{array}{l}\text { Sub- } \\
\text { urban }\end{array}$ & All \\
\hline $\mathrm{N}$ & 85 & 145 & 37 & 267 & 11 & 38 & 82 & 131 \\
\hline M & 81.1 & 1,075 & 1,020 & 983 & 746 & 1,203 & 1,138 & 1,124 \\
\hline SD & 215 & 193 & 203 & 234 & 218 & 175 & 222 & 239 \\
\hline $\min$ & 335 & 464 & 552 & 335 & 449 & 913 & 770 & 449 \\
\hline $\max$ & 1,294 & 1,552 & 1,384 & 1,552 & 1,052 & 1,608 & 2,116 & 2,116 \\
\hline
\end{tabular}

Table 11. Significance testing of diffenences between erythrocyte $\delta$-aminolevulinic acid dehydratase activity levels of Helsinki target groups.

\begin{tabular}{|c|c|c|c|c|}
\hline \multirow{2}{*}{ Groups tested } & \multicolumn{2}{|c|}{ Males } & \multicolumn{2}{|c|}{ Females } \\
\hline & $\mathrm{t}$ & $\mathrm{p}$ & $t$ & $\mathrm{p}$ \\
\hline $\begin{array}{l}\text { Streetsweepers vs. downtown } \\
\text { Streetsweepers vs. suburban } \\
\text { Downtown vs. suburban }\end{array}$ & $\begin{array}{r}-9.37 \\
-5.13 \\
1.51\end{array}$ & $\begin{array}{l}<0.001 \\
<0.001 \\
>0.1\end{array}$ & $\begin{array}{r}-6.37 \\
-5.59 \\
1.72\end{array}$ & $\begin{array}{l}<0.001 \\
<0.001 \\
\approx 0.08\end{array}$ \\
\hline
\end{tabular}

males but still had a higher mean than the Pertunmaa females. The $\mathrm{Pb}-\mathrm{B}$ values among Pohjois-Haaga males and females were of the same order of magnitude as the $\mathrm{Pb}-\mathrm{B}$ values of the streetsweepers.

\section{Erythrocyte $A L A D$ activity}

The ALAD values are listed in table 10 . For methodolagical reasons, the ALAD values of the policemen were omitted; these had been analyzed before the current modification of the ALAD assay was taken into use. The streetsweepers had significantly lower ALAD values than the downtown and the suburban group, whereas only minimal differences existed between the downtown and the suburban groups.

The results of significance testing between the groups are indicated in table 11. The males also had lower ALAD values than the females $(t=5.55, p<0.001)$. In this series the relationship between ALAD and $\mathrm{Pb}-\mathrm{B}$ yielded a correlation coefficient of $r=-0.37 \quad(p<0.001, N=419$, range 4-29 $\mu \mathrm{g} \mathrm{Pb} / 100 \mathrm{ml})$. Interestingly this negative correlation was still statistically
Table 12. Correlations between erythrocyte $\delta$-aminolevulinic acid dehydratase (ALAD) activity and blood lead $(\mathrm{Pb}-\mathrm{B})$ concentration after adjustment of the upper $\mathrm{Pb}-\mathrm{B}$ limit at varying levels. $\bar{y}=$ mean values of ALAD activity, expressed as $\mu \mathrm{mol} \mathrm{PBG} / \mathrm{h} / \mathrm{R} \mathrm{RBC} ; \overline{\mathrm{x}}=\mathrm{Pb}-\mathrm{B}$ mean values, expressed as $\mu \mathrm{g} / 100 \mathrm{ml}$.

\begin{tabular}{|c|c|c|c|c|c|}
\hline $\mathrm{Pb}-\mathrm{B}$ & $\mathbf{N}$ & $\overline{\mathrm{y}}$ & $\overline{\mathrm{x}}$ & $r$ & $\mathbf{p}$ \\
\hline$\leqq 15$ & 357 & 1,050 & 10.3 & -0.32 & $<0.001$ \\
\hline$\leqq 14$ & 335 & 1,056 & 10.0 & -0.32 & $<0.001$ \\
\hline$\leqq 13$ & 306 & 1,064 & 9.6 & -0.32 & $<0.001$ \\
\hline$\leqq 12$ & 281 & 1,078 & 9.3 & -0.27 & $<0.001$ \\
\hline$\leq 11$ & 241 & 1,097 & 8.9 & -0.20 & 0.01 \\
\hline$\leqq 10$ & 197 & 1,104 & 8.4 & -0.23 & $<0.001$ \\
\hline$\leqq 9$ & 145 & 1,135 & 7.8 & -0.13 & $<0.05$ \\
\hline
\end{tabular}

significant when all of the $\mathrm{Pb}-\mathrm{B}$ values over $10 \mu \mathrm{g} / 100 \mathrm{ml}$ were omitted from the calculations $(\mathrm{r}=-0.23, \mathrm{p}<0.001, \quad \mathrm{~N}=$ 197) (table 12).

No influence of age on the $\mathrm{Pb}-\mathrm{B}$ levels or the ALAD activity was detectable among any of the groups in question. This also applied to cigarette smoking with the exception of the streetsweeper group, in which a difference of $\mathrm{Pb}-\mathrm{B}$ mean values was found between cigarette smokers and 
Table 13. Effect of cigarette smoking on the blood lead $(\mathrm{Pb}-\mathrm{B})$ concentration and erythrocyte $\delta$-aminolevulinic acid dehydratase (ALAD) aotivity of Helsinki streetsweepers. (Pb-B values expressed as $\mu \mathrm{g} / 100 \mathrm{ml}$; ALAD as $\mathrm{PBG} / \mathrm{h} / \mathrm{l} \mathrm{RBC}$ )

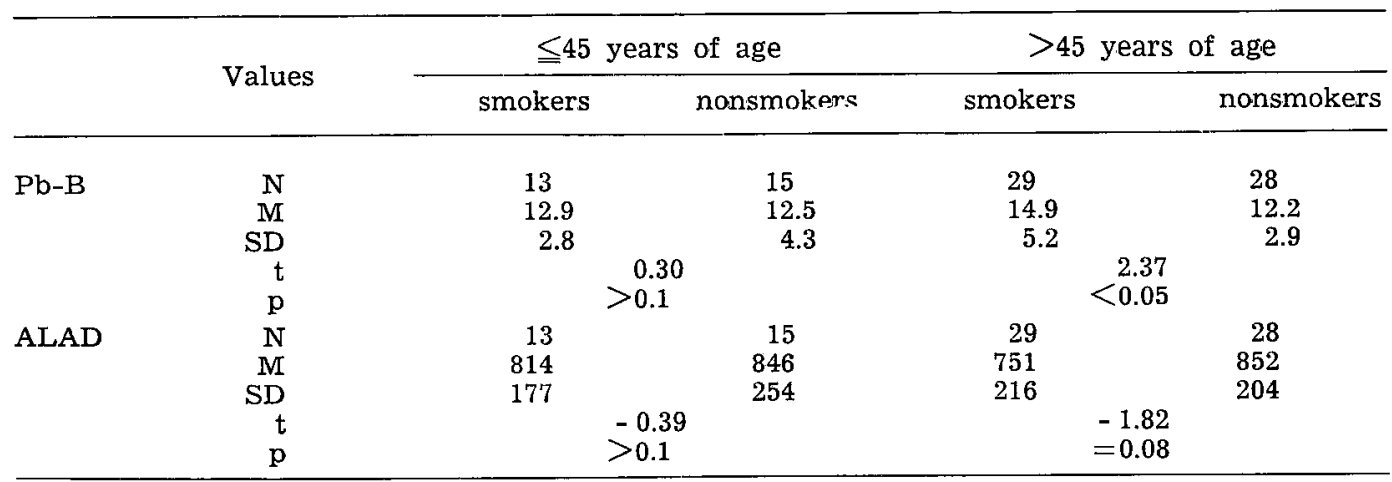

nonsmokers over 45 years of age (table 13). The difference was statistically significant at the $5 \%$ level $(\mathrm{t}=2.37)$. The ALAD values showed a slightly smaller difference between smokers and nonsmokers in the older group. No such differences were found in the younger group, 44 years of age of less.

\section{DISCUSSION}

The most striking result obtained is the low level of $\mathrm{Pb}-\mathrm{B}$ found in all the groups. As a whole the mean values for the urban and the rural population groups are about the lowest reported $\mathrm{Pb}-\mathrm{B}$ values for general populations. It is, however, difficult to achieve a satisfactory degree of comparability to other studies in the absence of intermixing.

When this study was begun, the $\mathrm{Pb}-\mathrm{B}$ assay was known to be vulnerable to systematic errors. As interpretation of the results would be completely dependent on the validity of the $\mathrm{Pb}-\mathrm{B}$ assay, great care was taken to ensure its accuracy and precision throughout the work. The precision appeared to be on a high level. The method error of duplicate measurements reported by the laboratories (1.1 $\mu \mathrm{g}$ / $100 \mathrm{ml}$ ), somewhat lower than that noted for a set of 26 duplicate samples analyzed unbeknown to the laboratory personnel $(1.7 \mu \mathrm{g} / 100 \mathrm{ml})$, is consistent with the findings of Berlin and his colleagues (2), who suggested that laboratories tended to reject outlying results when reporting. All of the $\mathrm{Pb}-\mathrm{B}$ values reported here were mean values of two parallel determinations; if the discrepancy between duplicate measurements exceeded $5 \mu \mathrm{g} / 100 \mathrm{ml}$, the analyses were repeated. This pnocedure probably accounts for the previously described differences.

In regard to accuracy, it is observable from the inter-Scandinavian comparison (table 3) that at the time our method showed somewhat higher $\mathrm{Pb}-\mathrm{B}$ values than did most of the other laboratories and our values were systematically higher than the mean values of the eight participating laboratories. The agreement between results obtained by the ASARCO laboratories and those of the Institute of Occupational Health was, especially at low $\mathrm{Pb}-\mathrm{B}$ levels, much closer than is usually found in interlaboratory comparisons $(1,2,26)$ (table 5). It can be concluded that, if anything, the values reported by the Institute of Occupational Health were systematically a little higher than the mean values of the reference laboratories.

The absence of differences between rural and urban $\mathrm{Pb}-\mathrm{B}$ levels also arouses interest. No differences were apparent between the downtown and the two rural population groups. The PohjoisHaaga group exhibited unexpectedly high $\mathrm{Pb}-\mathrm{B}$ values. The mean values of the lead in the air ( $\mathrm{Pb}-\mathrm{A})$ of Pohjois-Haaga were also surprisingly high, approximating the downtown levels. In all probability these are attributable to at least four leademitting sources apart from traffic. De- 
pendent upon the wind direction, these sources may have been: the main Helsinki incinerator, at a distance of about 5 kilometers east of Pohjois-Haaga; the Tikkurila lead plants, situated about 10 kilometers northeast of Pohjois-Haaga; a lead pigment plant at a distance of 1.5 kilometers west of Pohjois-Haaga; and the Haaga no. 3 power station in Pohjois-Haaga. Mattson and Jaakkola (34) have suggested that in particular the main Helsinki incinerator, but also the lead smelteries in Tilkkurila (fig. 1), may significantly contribute to the Helsinki $\mathrm{Pb}-\mathrm{A}$, and especially to that of Pohjois-Haaga.

The $\mathrm{Pb}-\mathrm{B}$ values of the Pohjois-Haaga females seem to indicate a measurable effect of $\mathrm{Pb}-\mathrm{A}$ amouniting to about $1 \mu \mathrm{g} /$ $\mathrm{m}^{3}$, whereas the downtown group did not exhibit any effect of this ikind. Nonetheless, it must be emphasized that the use of a few fixed sampling devices is an inadequate method for assessing the exposure of an entire population group. Furthermore, in population studies it is difficult to cope with interindividual variations of dietary lead intake that mask the influence of low lead concentrations in ambient air.

The finding that the streetsweepers had higher $\mathrm{Pb}-\mathrm{B}$ values is consistent with earlier reports $(29,32)$.

Cigarette smoking was not found to exert any effect upon $\mathrm{Pb}-\mathrm{B}$ within the groups of the general population. Only in the streetsweeper group over 45 years of age did the smolkers show higher $\mathrm{Pb}-\mathrm{B}$ values than nonsmokers. No such difference was discernible in the younger age group. The literature is controversial on this point. Some investigators have reported higher $\mathrm{Pb}-\mathrm{B}$ levels for smokers than for nonsmokers $(23,33,42)$, while others have been unable to detect such an effect $(13,30,35)$. It seems probable that in itself the inhalation of tobacco smoke does not have a measurable effect on $\mathrm{Pb}-\mathrm{B}$ levels. The differences reported are probably attributable to the ingestion of particles from contaminated fingers. The occurrence of the difference in the older groups alone presumably arose from hygienic differences between the age groups, decreased mucociliary activity and changes in the phagocytic capacity of macrophages in the older smokers, and a longer period of lead accumulation.
The sensitivity of the ALAD test has been established by many investigators $(6,7,17,18,19,21,36,44)$. Moreover, it has repeatedly been shown that the specificity is high (20) and the accuracy and precision are good $(1,4)$. It has been suggested that the ALAD assay, by virtue of these characteristics, would be suitable for population surveys $(1,3,4,21)$. Despite the exceptionally low $\mathrm{Pb}-\mathrm{B}$ levels found in the present study, the ALAD assay appeared to be sufficiently sensitive for discrimination between most groups in which the $\mathrm{Pb}-\mathrm{B}$ levels differed at a statistically significant level. The ALAD test failed to reflect only the differences found between the downtown and the suburban females and the differences between the two suburban groups. When the study was initiated, no experience had been gained with ALAD from population studies, but during its course some reseanchers reported on their experience with population studies in which the ALAD test was employed. Secchi and his colleagues, for instance, successfully applied the ALAD test in studies on varying population groups subjected to different degrees of environmental lead exposure $(39,40,41)$. The $\mathrm{Pb}-\mathrm{B}$ levels of those population groups from Milan, or the rural neighborhoods of Milan, however, were higher than the commonly reported levels for general populations. Also Lob and his coworkers were able to discriminate between a rural and an urban group of schoolboys by employment of the ALAD assay. The mean $\mathrm{Pb}-\mathrm{B}$ values of the two groups were 18.9 for the rural and $22.2 \mu \mathrm{g} / 100 \mathrm{ml}$ for the urban group (31). In contrast Kennedy and his colleagues (25) did not discover any relationship between ALAD activities and $\mathrm{Pb}-\mathrm{B}$ values below $25 \mu \mathrm{g} / 100 \mathrm{ml}$. Valloton and his colleagues (45) could not establish a significant correlation between $\mathrm{Pb}-\mathrm{B}$ levels and ALAD activities in people unexposed to lead by profession; neither did Coulston's team find any inhibition of ALAD in their 18-week chamber exposure study at $3.2 \mu \mathrm{g} \mathrm{Pb} / \mathrm{m}^{3}$ of air, although a distinict elevation of the $\mathrm{Pb}-\mathrm{B}$ levels oocurred. However, in an identically designed study at $10.9 \mu \mathrm{g} \mathrm{Pb} / \mathrm{m}^{3}$ of air, a distinct inhibition of the ALAD activity was noted $(11,12)$. These seeming discrepancies are probably attributable to methodological aspects. Close correlation 
between $\mathrm{Pb}-\mathrm{B}$ and ALAD necessarily calls for extremely high precision and sensitivity in both methods. These aspects become even more important when the range of variation is very narrow, as is the case in studies of the general population. The validity aspects of $\mathrm{Pb}-\mathrm{B}$ have already been discussed and will not be repeated here. In regard to the ALAD assay the most important feature is standardization of the $\mathrm{pH}$ value, which presupposes a stable buffer. Furthermore, all of the researchers referred to earlier used a $\mathrm{pH}$ of 7.0, which according to Nikkanen and his cowarkers (37) is less sensitive than the 6.8 employed here; however, the highest correlation coefficient was found by Nikkanen and his colleagues at a pH of 6.4. With $a$ view to the comparability between laboratories, it thus seems reasonable to recommend the standardized ALAD assay suggested by Berlin and Schaller (3) for future population studies; the method employs a pH of 6.4 and has been specially developed to suit low-level exposure to environmental lead.

An important feature of the results was that the negative correlation between $\mathrm{Pb}$ $B$ and ALAD was statistically highly significant $(\mathrm{p}<0.001)$, even at $\mathrm{Pb}-\mathrm{B}$ levels of $10 \mu \mathrm{g} / 100 \mathrm{ml}$ or below. This finding has a bearing upon the question of whether or not a threshold exists for the inhibitory effect of $\mathrm{Pb}-\mathrm{B}$ on ALAD activity. Both the conception of a threshold and that of a nonthreshold have their advocates. However, whether a threshold is obtained or not seems to be a question of the sensitivity and precision of the methods applied.

In the comparison of environmental exposure, the $\mathrm{Pb}-\mathrm{B}$ technique applied is currently the most straightforward method, although it calls for advanced equipment and skilled personnel. On the other hand, the ALAD assay is less expensive, less exacting, and has a higher interlaboratory comparability than the $\mathrm{Pb}-\mathrm{B}$ methad $(1,2,4)$. The only important drawback of the ALAD method is the lack of stability, which means that the analyses should be performed within $5 \mathrm{~h}$ of sampling (37). According to experience gained in this study, ALAD assay appears to be a useful epidemiologic tool for the comparison of environmental lead exposure in various populations.

\section{CONCLUSIONS}

From an international standpoint the $\mathrm{Pb}-\mathrm{B}$ levels of all the groups studied were low. No differences were observable between $\mathrm{Pb}-\mathrm{B}$ levels of downtown and rural residents despite the fact that the $\mathrm{Pb}-\mathrm{A}$ concentrations in Helsinki were 50 times as great. The Pohjois-Haaga $\mathrm{Pb}-\mathrm{B}$ levels were slightlly higher than the downtown levels although similarity was found in the $\mathrm{Pb}-\mathrm{A}$ concentrations. The difference may have originated from the following: (a) chance, (b) higher exposure to dustborne lead for the Pohjois-Haaga population, or (c) different emitting sources producing particles with different characteristics (chemical composition, shape, solubility) which may affect the rate of absorption $(27,28)$. Nonetheless, Helsinki traffic alone does not increase the $\mathrm{Pb}-\mathrm{B}$ levels of the general population to an extent that is significant in practice. The exposure of the traffic policemen and the streetsweepers to exhaust gas and dust is followed by a measurable increase in $\mathrm{Pb}-\mathrm{B}$ levels.

The ALAD assay proved useful for discriminating between separate groups whose $\mathrm{Pb}-\mathrm{B}$ levels differed to a small but measurable exitent. The negative correlation between $\mathrm{Plb}-\mathrm{B}$ and $\mathrm{ALAD}$ appeared, funthermore, to prevail at extremely low $\mathrm{Pb}-\mathrm{B}$ levels.

Age per se was not found to have any relationship to $\mathrm{Pb}-\mathrm{B}$ level.

\section{ACKNOWLEDGMENTS}

Raili Vilhunen, M.Sc. (Eng.), supervised the laboratory analyses. The statistical operations were performed by Erkki Järvinen, M.Sc. The results of the studies on air-suspended particulate lead in Helsinki and Pertunmaa were made available by the Department of Toxicology and Biochemistry of the Institute of Occupational Health.

This study has been financially supported by the Finska Läkaresällskapet.

\section{REFERENCES}

1. BERLIN, A., DEL CASTILHO, P. and SMEETS, J. European intercomparison programmes. Proceedings of the international symposium on the environmental 
health aspects of lead. Amsterdam, Oct. 1972, pp .1033-1044.

2. BERLIN, A., LAUWERYS, R., BUCHET, J. P., ROELS, H., DEL CASTILHO, P. and SMEETS, J. Intercomparison programme on the analysis of Iead, cadmium and mercury in biological fluids. International symposium-environment and health. CECEPA-WHO, Paris June 1974, no. 141.

3. BERLIN, $A$. and SCHALLER, $K$. $H$. European standardized method for the determination of $\delta$-aminolevulinic acid dehydratase activity in blood. Z. Klin. Chem. Klin. Biochem. 389 (1974).

4. BERLIN, A., SCHALLER, K. H. and SMEETS, J. Standardisation of ALA-D activity determinations at the European level: Intercalibration and applications. International symposium-environment and health. CEC-EPA-WHO, Paris June 1974 no. 119.

5. BERLIN, M., GAGE, J. and JONNSON, E. Increased aromatics in motor fuels: A review of the environmental and health aspeots. Work-environ-health 11 (1974) 1 -20 .

6. BONSIGNORE, D., CALISSANO, P. and CARTASEGNA, C. Un semplice metodo per la determinazione della $\delta$-aminolevulinico-deidratasi nel sangue. Comportamento dell'enzima nell'intossicazione saturnina. Med. lav. 56 (1965) 199.

7. BRUIN, A. DE and HOOLBOOM, H. Early signs of lead-exposure: A comparative study of laboratory tests. Br. $j$. ind. med. 24 (1967) 203.

8. CAMPBELL, K. Feedstocks for the petrochemical industry. Chem. ind. (London) 13 (1973) 601.

9. CEC: COMMISSION OF THE EUROPEAN COMMUNITIES. Air lead concentrations in the European community: Yearly report: April 1971 - March 1972. Office for Official Publications of the European Communities, Luxembourg Sept. 1972.

10. CHOW, T. J. and EARL, J. L. Lead aerosols in the atmosphere: Increasing concentrations. Science 169 (1970) 577.

11. COULSTON, F., GOLDBERG, L., GRIFFIN, T. B. and RUSSEI, J. C. The effects of continuous exposure to airborne lead: II. Exposure of men to particulate lead at a level of $10.9 \mu \mathrm{g} / \mathrm{cubic}$ meter. Institute of Experimental Pathology and Toxicology, Albany, N.Y. 1973, pp. $1-21$.

12. COULSTON, F., GOLDBERG, L., GRIFFIN, T. B. and RUSSEL, J. C. The effects of continuous exposure to airborne lead: IV. Exposure of men to particulate lead at $a$ level of $3.2 \mathrm{~kg} / \mathrm{cubic}$ meter. Institute of Experimental Pathology and Toxicology, Albany, N.Y. 1973. 52 p.

13. DAINES, R. H., SMITH, D. W., FELICIANO, A. and TROUT, J. R. Air levels of lead inside and outside of homes. Ind. med. surg. 41 (1972) 26.

14. EPA: UNITED STATES ENVIRONMENTAL PROTECTION AGENCY (Health Effects Branch). EPA's position on the health effects of airborne lead. Office of Research and Monitoring, Washington, D.C. Nov. 1972.
15. GÖTHE, C. J., OHMAN, H. and LINDSTEDT, G. Expasure to airborne lead in city atmosphere. Work-environ.-health 10 (1975) 13-18.

16. GRENNFELT, P., AKERSTRÖM, Å. and BROSSET, C. Determination of filtercollected airborne matter by X-ray fluorescence. Atmos. environ. 5 (1971) 1.

17. HAAS, T., MACHE, K., SCHALLER, $K$. H. and VALENTIN, H. Die Delta-Aminolävulinsäure-Dehydratase als wertvoller biochemischer parameter bei der Überwachsung von Bleiarbeitern. Arbeitsmed. Sozialmed. Arbeitshyg. 6 (1971) 303.

18. HAEGER-ARONSEN, B., ABDULLA, M. and FRISTEDT, B. I. Effect of lead on $\delta$-aminolevulinic acid dehydrase activity in red blood cells. Arch. environ. health 23 (1971) 440.

19. HERNBERG, S. and NIKKANEN, J. Enzyme inhibition by lead under normal urban conditions. Lancet 10 (1970) 63 .

20. HERNBERG, S. and NIKKANEN, J. Effect of lead on $\delta$-aminolaevulinic acid dehydratase: A selective review. Prac. lek. 24 (1972) 77.

21. HERNBERG, S., NIKKANEN, J., MELLIN, G. and LILIUS, H. $\delta$-aminolevulinic acid dehydrase as a measure of lead exposure. Arch. environ. health 21 (1970) 140.

22. HESSEL, D. W. A simple and rapid quantitative determination of lead in blood. At. absorpt. newsl. 7 (1968) 55.

23. HOFREUTER, D. H., CATCOT, E. J., KEENAN, R. G. and ZINTARAS, C. The public health significance of atmospheric lead. Arch. environ. health 3 (1961) 568.

24. HORIUCHI, $K$. Lead in the environment and its effect on man in Japan. Osaka city med. j. 16 (1970) 1.

25. KENNEDY, G. L., DRESSLER, I. A. and KEPLINGEN, M. L. Relationship of delitaamino levulinic acid dehydratase (ALAD) and blood lead levels in normal and lead exposed populations. Am. ind. hyg. assoc. j. 33 (1972) 2.

26. KEPPLER, J. F., MAXFIELD, M. E., MOSS, W. D., TIETJEN, G. and LINCH, A. L. Interlaboratory evaluation of the reliability of blood lead analysis. Am. ind. hyg. assoc. j. 31 (1970) 412.

27. LAWTHER, P. J., COMMINS, B. T., ELLISON, J. M. and BILES, B. In: P. HEPPLE (ed.), Lead in the environment. Institute of Petroleum, Landon 1972.

28. LAWTHER, P. J., COMMINS, B. T., ELLISON, J. M. and BILES, B. More observations on airborne lead. Proceedings of the international symposium on the environmental health aspects of lead. Amsterdam Oct. 1972 , pp. 373-389.

29. LEHNERT, G., MASTALL, H., SZADKOWSKI, D. and SCHALLER, K. H. Berufliche Bleibelastung durch Autoabgase in Grassistadtstrassen. Dtsch. Med. Wochenschr. 15 (1970) 1097.

30. LEHNERT, G., SCHALLER, K. H., KƯHNER, A. and SZADKOWSKI, D. Auswirkungen des Zigarettenrauchens auf Blutbleispiegel. Int. Arch. Gewerbepathol. Gewerbehyg. 23 (1967) 358. 
31. LOB, M., GUILLEMIN, M., MURSET, J. C. and PERELYGUINE, I. Plombémie, acide $\delta$-aminolévulinique et déhydratase de l'acide $\delta$-aminolévulinique (Résultats comparés entre écaliers de la ville et de la campagne). Schweiz. Med. Wochenschr. 102 (1972) 1751.

32. LORANT, P. and SVOBODA, K. Untersuchungen über die Bleibelastung Strassenstaubexponierter Berufsgruppen in Wien. Arbeitsmed. Sozialmed. Präventivmed. 8 (1973) 95.

33. LUDWIG, J. H., DIGGS, D. R., HESSELBERG, H. E. and MAGA, J. A. Survey of lead in the atmosphere of three urban communities: A summary. Am. ind. hyg. assoc. j. 26 (1965) 270.

34. MATTSSON, R. and JAAKKOLA, T. Helsingin ilman lyijypitoisuudesta. [Lead in the Helsinki air] Ympäristö ja terveys 5 (1974) 721.

35. MC LAUGHLIN, M. and STOPPS, G. J. Smoking and lead. Arch. environ. health 26 (1973) 131.

36. MILLAR, J. A., CUIMMING, R. L. C., BATTISTINI, V., CARSWELL, F. and GOLDBERG A. Lead and $\delta$-aminolaevulinic acid dehydratase levels in mentally retarded children and in lead-poisoned suckling rats. Lancet 3 (1970) 695.

37. NIKKANEN, J., HERNBERG, S. and TOLA, S. Modifications of the deltaaminolevulinic acid dehydratase test and their significance for assessing different intensities of lead exposure. Work-environ.-health 9 (1972) 46.

38. PHILIPS. The analysis of aerosols using an $X$-ray sequantial, semiautomatic spectrometer (Bulletin Dec. 1973). Analytical Equipment Department, N. V. Philips Gloeilampenfabrieken, Eindhoven, The Netherlands 1973, pp. $1-4$.
39. SECCHI, G. C. and ALESSIO, L. Laboratory results of some biological measures in workers exposed to lead. Arch. environ. health 29 (1974) 351.

40. SECCHI, G. C., ALESSIO, L. and CAMBIAGHI, G. Ricerche sull'attivita' aladeidrasica eritrocitaria de soggetti non esposti a contatto professionale con piombo ed abitanti in zone rurali ed urbane. Med. lav. 62 (1971) 435.

41. SECCHI, G. C., ALESSIO, L., CAMBIAGHI, G. and ANDREOLETTI, F. ALAdehydratase activity of erythrocytes and blood lead levels in "critical" population groups. Proceedings of the international symposium on the environmental health aspects of lead. Amsterdam, Oct. 1972, pp. 595-602.

42. TEPPER, L. B. and LEVIN, L. S. A survey of air and population lead levels in selected American communities. Department of Environment Health, Kettering Laboratory, University of Cincinnati, Cincinnati, Ohio Dec. 1972, pp. 1-73.

43. THOMAS, H. V., MILMORE, B., HEIDBREDER, G. A. and KOGAN, B. A. Blood lead of persons living near freeways. Arch. environ. health 15 (1967) 695.

44. TOLA, S. Erythrocyte $\delta$-aminolevulinic acid dehydratase as a test for lead exposure. Doctoral dissertation, University of Helsinki, Helisinki May 1973, pp. 1-52.

45. VALLOTON, M. N., GUILLEMIN, M. and LOB, M. Plombémie et activitéde la déhydratase de l'acide $\delta$-aminolevulinique dans une population lausannoise. Schweiz. Med. Wochenshr. 103 (1973) 547.

46. WALDRON, H. A. Lead levels in blood of residents near the $\mathrm{M} 6-\mathrm{A} 38$ (M) interchange. Birmingham. Nature 253 (1975) 346 